DOI: https://doi.org/10.47405/mjssh.v6i3.725

\begin{tabular}{|c|c|}
\hline & Malaysian Journal of Social Sciences and Humanities (MJSSH) \\
\hline 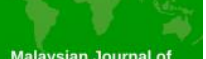 & Volume 6, Issue 3, March 2021 \\
\hline Humanities & e-ISSN : 2504-8562 \\
\hline & $\begin{array}{l}\text { Journal home page: } \\
\text { www.msocialsciences.com }\end{array}$ \\
\hline
\end{tabular}

\title{
Exploring the Natural Attributes of Principals as Educational Leaders
}

\author{
Rohani Binti Marasan'1, Andrew Lim¹, Dg. Norizah Ag. Kiflee @ Dzulkifli1, Colonius Atang1 \\ ${ }^{1}$ Universiti Malaysia Sabah (UMS)
}

Correspondence: Rohani Binti Marasan (rohanimarasan70@gmail.com)

\begin{abstract}
This study sought to explore the leadership of principals as educational administrators based on their natural attributes. The excellence in the actions of principals as educational administrators will serve as the determining factor for the success of a school across nine fields listed in the Malaysian School Principals Competency Standards. This success is mainly driven by the natural attributes of principals' leadership in influencing the processes and behaviour of teachers in the delivery of education. This study also explores leadership issues and problems that are still of current interest. Principals' competency levels in executing leadership still show that teachers are constrained by numerous flaws particularly in the teaching and learning in schools. Such conditions are often mirrored in schools with poor leadership display by Principals who are bent on putting off planned educational programmes. This qualitative study was done as a single case study. Qualitative data obtained via interviews with 10 informants in school formed the research case. The interviews were semi-structured and were analysed manually using category classification. The interviews explained the natural attributes reflected via Principals' leadership orientation to answer the issues in this study. The findings of this study shall serve as additional elements in the process of selecting and placing Principals, as well as be developed as a guide for educational administrators desiring effective and quality leadership orientation for managing and administrating schools in Sabah. This study is of importance as it contributes additional knowledge in the fields of education and human resource for the benefit of other researchers.
\end{abstract}

Keywords: principal, natural attributes, leadership orientation

\section{Introduction}

The Malaysia Education Blueprint 2013-2025 (known as Pelan Pembangunan Pendidikan Malaysia, or PPPM) launched in 2013 has its focus on among others, the quality of school leadership as well as the quality of teachers in $21^{\text {st }}$ Century Learning (referred locally as Pembelajaran Abad Ke-21 or PAK21). The challenges of changing times have brought about a shift towards a highly informed and technology-literate society. The focus on a knowledgeable society as well as the concept of networking in the face of global economy defines a dynamic way of life which known as a world without borders.

The Ministry of Education's (MOE) decision to bring a paradigm shift in principals' leadership practices are in line with the demands of present-day society. School leadership under the charge of principals are expected to satisfy Key Performance Indicators laid out by the MOE in the National Key Result Areas (NKRA) and PPPM. Hence the need for more dynamic and excellent leadership by principals in schools. The next element concerns values sought by society, particularly parents. In effect, principals' leadership form the apex for the implementation of the MOE's policies as enshrined 
in the National Education Philosophy. Their wisdom in governing serves as a source of inspiration for teachers under their charge.

Available literature reveals that relatively few studies on principals' leadership have been done with specific reference to their natural attributes or characteristics. The lack of knowledge of this phenomenon means that exploration of studies on principals' leadership are still relevant and unique. Thus so, the MOE's policymakers may utilise this study as reference for creating leadership management training in schools to dignify the teaching professionalism in future. Besides, the findings of this study can serve to encourage the implementation of principals' leadership in secondary schools in Sabah.

\section{Background of the Study}

In the field of Education, principals have attested that leadership plays a pivotal role in ensuring the success and excellence of a school. The Malaysian School Principals Competency Standards (MSCPS) mentions this matter clearly. Studies on leadership have mainly focused on popular leadership strategies such as distributed leadership, instructional leadership, and transformational leadership. Meanwhile, less attention has been afforded to studies on leadership regarding natural attributes. Hence there exists a gap in research on leadership especially in the state of Sabah. Furthermore, most studies have been quantitative based while this study was done through qualitative methods.

A study on principals' leadership success by Bity Salwana Alias, Ahmad Basri Md. Yusof, Ramlee Mustapha and Mohamad Jani Ibrahim (2010) summarized that principals must possess the necessary competencies to be able to act exceptionally in managing and leading schools. They found that successful principals comprise leaders with personal touch and professional attitude as well as capable of forecasting and adapting leadership to suit the school's needs. This study believes that leaders are born with natural talents or personality traits that make them leaders. These natural attributes will be explored to serve as reference for the selection of future principals in every school. The success of a school is dependent on its Principal as leader and source of inspiration (Sharifah Madinah, 2007). Teachers will esteem principals and this will certainly uplift society's views towards the professionalism in teaching.

Principals are leaders based on policies practised in schools (Ellen Wexler Eckman, 2017). In the efforts to develop a school, it is necessary for principals to set their targets through clear and principled Key Performance Indicators KPI). Principals must also take upon the role of leaders in current technology as a step towards achieving high performance school (Khadijah Daud, 2017). These studies explain that principals need to be proactive and adaptive towards the current challenges. Studies on principals' leadership demonstrate a decline in students' academic performance (Mitchell, Kensler, Tschnnen-Moran, 2015). This results from organizational leadership that is too focused on learning that involve different school levels. Instructional leadership has been regarded as highly motivating since the 1980 s and has spread till present. Hence, a principal's duty is no longer limited to administration per se (Hitt and Turcer, 2016). Principals who succeed in developing a school need to emphasize the importance of instructional leadership raising its students' academic performance. Instructional leadership also offers motivation to teachers under the principal's charge (James, 2018).

In raising the standard of teaching professionalism, effective school leadership is when the principal places emphasis on the need of education by means of collaborative leadership (Wan Noor Adzmin, 2017 dan Muhammad Rozaimi Ramle, Jamal @ Nordin Yunus, 2016). Rosenblum et. al (1979) explains the leadership of a Principal as an educational administrator who has potential.

\footnotetext{
"In many ways the school principal is the most important and influential individual in any school. He or she is the person responsible for all activities the occur in and around the building. It is the principal's leadership that sets the tone of school, the clime for learning, the level of professionalism and morale of teachers
} 
DOI: https://doi.org/10.47405/mjssh.v6i3.725

and the degree of concern for what students may or may not become"

The arguments of previous studies advocate that leadership issues are still relevant for study, more so in an increasingly dynamic education world. With this basis, the researcher therefore believes that as an education administrator, a principal plays the prime role in developing a school.

\section{Statement of the Problem}

A leader in Mahathir Mohamad's (2016) opinion needs to be prepared with knowledge and personal skills to helm increasingly challenging leadership. In Malaysia, the education sector especially needs personnel who are professional, creative, proactive, and competent as authoritative leaders besides having a God-fearing consciousness in living an honourable life. Therefore, it is fitting for educational leaders such as principals to possess extraordinary higher order skills to be able to compete in the digital age.

The issues and problems focused on in this study revolve around principals who still do not reflect professional leadership as required by the MOE. This requirement in stipulated in the fifth shift of the Malaysia Education Blueprint 2013-2025, which clearly states that quality leadership must be accessible throughout every secondary school, be it urban or rural. The importance of principals' leadership is thus indispensable to produce successful schools despite having accreditation of the Professional Qualification Certificate, namely NPQEL.

One view holds that school leader are shaped from Principals' Competency or the Aminuddin Baki Institute's Version Of High Impact School Heads (Mustamin dan M.Al-Muz-zammil Yasin, 2012). Studies on principals' competence show that teachers are still bogged by accumulated flaws in teaching and learning in schools. This phenomenon still exists in secondary schools. The percentage of failures in the Literacy and Numeracy Screening (LINUS) are among the flaws resulting from the incompetence of principals in addressing students' low achievement. In fact, principals have also caused students to be left out of Higher Order Thinking Skills (HOTS) and $21^{\text {st }}$ Century Learning (PAK21).

This issue needs to be tackled urgently. Any neglect would hamper the MOE's efforts to raise the standard of teachers' professionalism. These problems stem from the failures of principals in carrying out their responsibilities wholeheartedly. As a result, policy planning is hindered, and society's views towards the teaching profession take a negative turn.

Negative remarks have been hurled towards principals for their unprofessional action on essential matters in school. This happens when those appointed as principals lack vision in their career. It has been said that such principals are incapable of exploring their ability to perform their duty and responsibilities with conviction. If prolonged, the whole education system will be viewed negatively by society who have always upheld schools as a second family institution. Such trust should never be left to erode. Therefore, the problem highlighted in this study is still relevant to be explored for the purpose of seeking solutions to overcome the challenges of education in an increasingly challenging digital era.

\section{Objective of the Study}

The objective of this study is to explore the natural characteristics or leadership attributes of principals in raising the standard of teaching professionalism.

\section{Importance of the Study}


This study will enable identification of natural characteristics or attributes found principals' personal leadership qualities. While a school's success and excellence only serves as catalyst to all parties to achieve the MOE's vision, it should also be made a priority factor in the policy of appointing secondary school principals' instead of basing solely on seniority.

This study will also provide new knowledge on principals' leadership in schools. It is hoped that this study will fill the gaps of knowledge on successful school leadership in Malaysia, Asia and the West through adaptation of local culture tailored to the needs of Sabah schools It will also serve as reference for future academic research focusing on principals' leadership to produce new literature and add new knowledge on educational management.

\section{Natural Attributes}

Natural attributes refer to the attraction possessed by a leader in terms of his/her leadership character. Attractive and dynamic personal values bring various advantages to an organization. Mitgang (2012) explains that principals with good leadership will be capable of raising the quality of the staff, teachers, and community of the school. This statement is supported by Norlia's (2014) research which successfully identified principals' attributes that bring about excellent leadership. The study involved factor analyses comprising intellectual, visionary, inspirational, competent, and self-efficacy. The properties of the attributes listed by these two researchers prove that research on principals' leadership based on natural attributes can be measured and will bring impact on those leadership influences.

Du Brin (2013) further explains that a visionary leader is one who is forward-thinking and brings benefit to all parties. The researcher concurs with Du Brin that visionary leaders are vital. Visionary leaders are capable of forecasting possible events and prepare action plans for such eventualities. A study done by Garba, Soaib and Ramli (2014) in Nigeria shows that a large portion of attribute-based influence is key to the effectiveness and performance of a school. Meanwhile, Ali Mohd Jubran Saleh's (2014) study on Islamic schools in Jordan found that their principals had positive attitudes. These findings illustrate that there are still points of interest and gaps to be looked into by researchers of leadership, including this study.

Willenberg's (2014) study advocates that successful leadership equals having natural attributes of leadership ability. This can also be proved through the leadership skills and relationship between leaders and their subjects. It is this relationship that creates positive memories. Besides, a leader needs to be able and passionate, have integrity, care for their subjects, and be in good health. Norlia Goolamally and Jamil Ahmad's (2014) study concurs that natural attributes of principals' leadership refers to the five traits or attributes, namely integrity, visionary, inspirational, competent, and selfefficacy. These attributes spur effective schools. Attributes are essential in regaining the trust and loyalty towards leadership in any organisation.

A qualitative study by Roselena Mansor (2015) focused on the competencies needed to make leadership effective. It found that the indicators of leadership competencies are well-informed leadership, skilled, having positive personality, contributiveness towards the organisation, and willingness to lead. In short, principals' leadership potentials are also dependent on the quality of their competence in carrying out the leadership duties. Other similar studies propose excellent character as an attribute to effective school leadership. Mun Jun Hao and Yazdanifard (2015) note that leadership is the influencing factor to the effectiveness of an organisation. This shows that a positive attitude is among the qualities needed in a leader. Previous researchers have found positive attitude to be a very dominant attribute.

Both researchers agree that positive attitude is a natural attribute that affects the effectiveness of leadership in schools. Norhannan Ramli's (2017) study on leadership states that leadership is closely related to the personality, behaviour, and quality of a leader. This implies that leadership without any element of force will drive leaders to form positive relationships with his/her subjects. This is 
supported by the theory of The Great Man which states that leadership personality is by virtue of birth, rather than inherited, conditioned, or trained (Manoj Kumar Sharma and Shilpa Jain, 2013).

This study is further supported by Kamal M. Surji (2015), who lists a number of factors influencing effective leadership, namely listening, serious-minded, responsible, passionate, strict, empowering, supportive, humble, and inspiring in planning. These competencies explain that natural attribute qualities are necessary among leaders. This finding also hints of positive attitude attributes. Therefore, personal quality competencies are necessary attributes for principals' leadership as head of organisation.

Aydin Bayler (2017) in his study on trust towards principals, referred to knowledge and skills. He also mentioned honesty as character, integrity and authentic, and openness towards leadership. Studies on female principals are also capable of explaining leadership success as indicator of leadership success. There is still room to explore such studies and it would be interesting to compare effectiveness of leadership based across demographics. Exploration of such studies could contribute to maturity of principals in schools., as well as measure principals' leadership against these demographic factors. Filling this research gap will be very meaningful for researchers interested in studies of leadership based on gender factors mentioned by Spector (2016). Among other indicators that explain leadership based on natural attributes is by referring to kindness. Humans strongly desire for good and credible leadership (Desmond M Tutu, 1984). This belief increases the level of trust towards the leadership. Leadership in schools revolve around the principal as the backbone. Principals need to practise leadership of quality. The indicator of kindess is among the personal qualities necessary of leaders such as principals. Principals who practise kindness will always gain the attention of teachers, students, and parents. Kind principals always reflect on mistakes as challenges in his leadership. Therefore, principals with this quality will strive to better understand and assist the surrounding people. More so when dealing with a problematic teacher, a kind principal will deal with the problem tactfully rather than by force or pressure.

This indicator is supported by principals' roles that are ever changing according to the times and the demands of society. In fact, future principals need to be forward thinking, wider and sophisticate in their contextual thinking and school transformation methods through groups or individuals. It is also one of the leadership indicators need by principals as educational administrators who possess the attribute of personal quality. Principals' leadership that is flexible and adaptable to the times is important as it reflects their wisdom. Principals continually strive to understand how great the need for transformation to face the changes in the world of education. If principals do not embrace change, they risk being labelled as irrelevant or backward. Hence, in the field of education, educational changes must be initiated by principals.

In this era of globalisation, principals are also scrutinised over nine areas of management as contained in the Malaysian School Principals Competency Standards Instrument. Wide-ranging states of discipline too have become the focus of principals' leadership due to its link to the effectiveness a given school's leadership. It is therefore essential for principals to be assertive, firm, and bold to face the various risks in managing students' discipline as well as facing a myriad of parents' reactions. Such strength will portray principals' leadership style in dealing with important social issues through education in school.

Sohiron, Ahmad Syukri dan Kasful Anwar US, (2019) explains that one necessary attribute for leaders is empathy. Their study notes the importance of empathy among principals as a means of understanding others. They advocate that it is imperative for principals to have high levels of empathy in executing their duties and to always strive to understand the feelings of teachers having issues in carrying out educational activities.

The openness of principals towards such matters will allow room for teachers to increase their teaching professionalism. There are teachers who want their leaders to join them in carrying out duties rather than merely give orders. As such, teachers have pointed towards principals' authority as cause of failure of certain matters in schools. Hence the advantage of openness will bring motivation to 
teachers. Principals who are always by their teachers will be trusted and esteemed more. This attitude must therefore be upheld as a role model to their subjects, particularly teachers. Becoming a great role model also requires sacrifice and whole-heartedness among principals in executing duties as an educator. Principals serve as the centre of reference for numerous matters big and small in school. Complacency among principals will result in teachers belittling their authority. Hence principals need to be intellectual and wise in managing bureaucracy and challenging school environments.

Education must prepare quality human resources, trained and ready to fulfill the demands of society. Effective educational leaders will also be able to practise competencies in the schools under their charge. In fact, these competencies can inspire teachers and the school community to contribute ideas in the process of achieving their school's vision. In addition, they will assist in the execution of an effective process of change through improvements in teaching and learning, besides encouraging effective relationship between school and community. This has been addressed in studies on the roles of Malaysian school principals highlighting the situation of a centralised system, where the burden and accountability placed on the principal are high and complex.

Principals' leadership is the determining factor in managing a critical process of change. Principals act as an intermediary agent in balancing the demands of the Ministry of Education of Malaysia and the limitations that needs to be faced in schools to formulate the process of change. Hence there exists many dimensions to evaluate the leadership of principals in schools. Centered on that focus of leadership, this study was conducted to strengthen the notion that effective leadership of principals in schools are driven by natural attributes greatly influences leadership. Leadership that is directed and focused on positive action should result in excellent school development.

The roles and functions of a principal is of indispensable importance in setting the course or ensuring the success of a school. Such is the recognition accorded that society regards teaching as a noble profession. This leadership study also reveals that the efficacy of principals is determined by their natural attributes and actions that are referred to, based on the behaviour of principals interacting with teachers and the school community. These are the indicators to show principals' leadership efficacy if they are continually practised in schools. The natural attributes indicators as mentioned can be seen during the researcher's field visit for the data gathering process. This discovery shall be discussed in detail to compare the researcher's findings to that of past researchers.

\section{Methodology}

This study is a qualitative single case study that gathered data through in-depth, semi-structured interviews. The data gathering focused on principals and administrative heads as well as teachers. The researcher employed in-depth interview, observation, and document analysis as her data gathering techniques. Interview protocols and observation were used to facilitate the field work. A total of 10 participants were successfully interviewed by the researcher. At the beginning stage, the researcher employed a theoretical framework to help build themes to ease categorisation of data gathered. The data were categorised according to the orientation of administration in the schools.

In the context of this study, the researcher employed purposive sampling where a total of 10 participants were selected. They comprised one principal, five senior assistants, two male and two female teachers with over five years of experience in their current school. These participants were selected based on the criteria laid out by the researcher, which are teachers who are closest to the principal's leadership. These informants are deemed capable of providing the information needed for this study. Such was to ensure focused execution of this study and clarity of data to fulfill its objectives.

This study employed semi-structured interviews whereby the informants had the freedom to voice their stream of thought towards the leadership of principals. All the interview sessions were then transcribed in verbatim by the researcher. The researcher used a voice recorder during the interview sessions to 
ensure no loss of data. A total of 10 interview sessions were conducted through the sampling method employed.

In addition, the observation technique was also used, whereby the researcher conducted observations on events related to leadership. As for the document analysis technique, the researcher gathered management-related documents such as minutes of meetings reports of performance improvement programmes, disciplinary reports, and performance reports available in school. Also included were related letters and documents from the MOE, State Department of Education, and District Education Office.

Appropriateness and trustworthiness were checked through audit trail and member checking. This study took a long six months to complete. Data were gathered in qualitative form. Audit trail was used to ensure reliability of the data gathered. The selection of the sampling technique was to enable gathering of data from informants who meet the criteria desired by the researcher for this study. The school involved was also selected to fit the design of this study. In fact, this school was selected as a case study. Peer review and expert review were conducted as validation procedures for this qualitative study. The informants were asked to re-read the questions in the interview protocol and the transcript prepared by the researcher. This was to ensure a match of information and that the product of the interview was in line with the aim of the study. In conducting expert review, the expertise of the research supervisor was given precedence to ensure the research adhered to research ethics throughout the course of the study. Finally, all the data gathered with themes appropriate to the research objectives were triangulated via observation and document analysis.

\section{Analysis of the Research Data}

The themes identified were categorized as positive natural attributes, professional attributes, and solidarity attitudes. The findings of the research data will focus on natural attributes through professional practice which is found to be the orientation for principal's leadership.

\section{ProfessionalAttributes}

Principals also practice professional attributes in executing their duty of implementing policies and meeting the demands of society, particularly parents. It is found that the principal would discuss what he desires to do for the school and its community in his capacity as principal to face the demands of society. The principal also carries wisdom in evaluating his teachers through the expertise and skills that he possesses. Such expertise is the strength that should be harnessed by principals to produce optimized work quality.

Table 1: Interview Analysis: Professional Attributes Themed

\begin{tabular}{lcc}
\hline Category & Subcategory & Sub-subcategory \\
\hline & & \\
Professional Practise & Clear Istruction & \\
& Quick Action & join \\
& Participative & expert \\
& Source of Reference & \\
\hline
\end{tabular}

Table 1 shows some of the natural attributes through professional practice that are practiced by the principal in school. The explanation on this practice is focused on subcategories such as clear instruction, quick action, participative, source of reference, exemplary and their effects on the principal's leadership.

\section{Professional Practice}


Student issues were quicky solved by the principal. He did not delay or wait for new issues to surface. The principal's action was proactive and should be modelled after. Such action is vital to prevent further issues. Quick and competent management reflects the true characteristic and behaviour of leaders. The principal dealt with the discipline problem the same way as mentioned by the informant in this study. The researcher believes that the principal's action is an act of professional practice because discipline problems and student-related issues of numerous sorts are bound to routinely exist in school. As such the principal takes the risk of meeting the parents in tackling student discipline problems.

This practice is supported by the other teachers, especial the Senior Assistant of Student Affairs. The principal is always in the school grounds. Should any discipline problem occur, the parents will deal directly with the principal regarding their children's problems. The principal's readiness helps in quicker solving of discipline problems. This scenario makes the informant feel guided even though he is new appointed to his post. the principal's involvement in student affairs shines of responsibility through his natural attributes. The principal himself acts to punish students without delay.

The above scenario illustrates the principal's degree of concern towards students' problems. More so in a borderless world transformation setting. The ever-growing student problems call for swift action by the principal. Discussions with parents are found to yield positive impact on how the principal appreciates the events. For the researcher, the principal's action needs to be in line with his words, coupled with reasonable and consistent action in his efforts to handle problematic students. It is such professional practice that becomes an influence towards the orientation of the principal's leadership.

Yes, help. Very humble as we can.

Why not... We face students as we are entrusted to... if students have problems we don't simply turn them away. We need to appreciate if we know their problems. We are their second parents.)

When pondering the words spoken by the principal, "we shouldn't block them out", we observe a reality where students have a second chance. In essence, the principal believes that humans can change. In fact, the principal encourages teachers to ponder the problems faced by students. Only then can teachers understand the students. According to the principal, teachers are also the students' second parents. In is thus clear that the principal's natural attributes in terms of personal concern is able to provide strength in leading through the challenges of school discipline with professional practice.

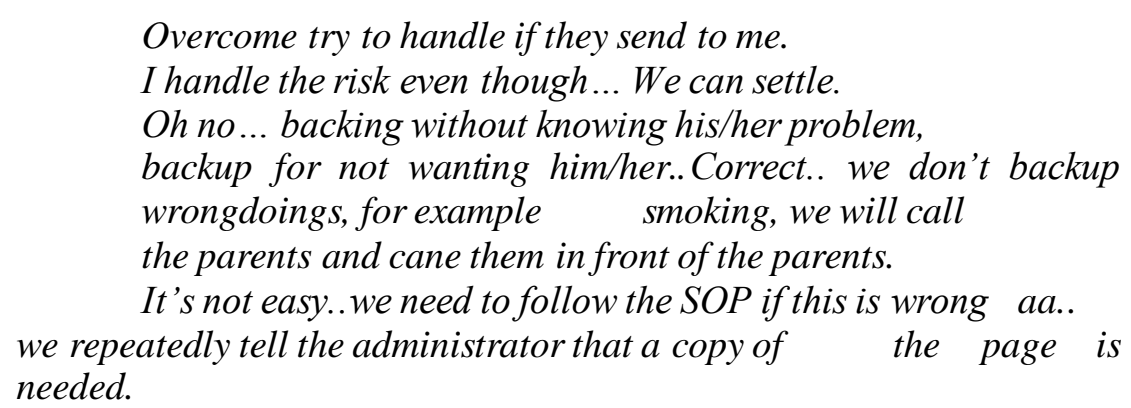

[TB/I1/S33-37]

The principal states that most novice teacher do not multitask and often rebel. Apart from that, teachers who possess higher academic qualifications and Super Teachers also create issues when given more teaching periods, for instance. Such teachers, in the principal's eyes, do not appreciate their duties as teachers. The shortcomings faced in school should best be overcome wholeheartedly, i.e., being teachers with soul. If the 'teacher soul' is rooted in them, then no question would arise when receiving instructions from their head of department. 
DOI: https://doi.org/10.47405/mjssh.v6i3.725

There's plenty of nagging when we talk about human

Resource there are teachers who do not appreciate.

They pretend.. do not appreciate.

Certainly not multitasking.

[TB/I1/S20-22]

Interview data from the Afternoon Senior Assistant informant, meanwhile, touched on the principal's attribute in doing the right thing and following Standard operating Procedures (SOP). Such rules and practice are part and parcel of civil servants' duty. This is the guideline that ought to be followed for more professionalism.

\author{
Of course... just now I mentioned two \\ already..yes..passion.. he does it immediately..does more \\ things correctly. he is positive and follows SOP...very \\ ambitious. in arrying out his duties he ensures the level.. \\ is the highest level of work. at the same time I like it \\ despite the being high.
}

[TB/I5/S5]
: $\quad$ he adheres to SOP. He is answerable... for any
mistake committed by the teachers, he has to
apologize to the public)

[TB/I6/S16-17]

\begin{abstract}
: $\quad$ Of course.. strict in terms of compliance to SOP.. must be appropriate I observe that he has done his homework, he knows the SOP. When teachers approach he can show why something needs to be done. After much reflection, I observe why the principal often increases the PCG is because he knows it can... just like our participation in competitions, can help many students to improve their academic performance.
\end{abstract}

These interview extracts above illustrate that the shared views between the administrators and teachers. They concur with the principal who acts according to professional attributes by acting according to SOP. Such a move is based on policy and rules. The informant states that the principal is answerable if there be any wrong in his action.

\title{
Clear Instructions
}

The principal's capability is also seen in his positive attitude towards the execution of his school as an excellent cluster school. The principal carries the responsibility of executing the education system according to the mould and procedures determined by the higher authorities. It is said that he foresees the advantages of his school compared to ordinary schools more than he sees the possible problems to be faced with. Such positive attitude is also seen when the principal gives clear and precise instructions without confusing his teachers. This includes instructions sent through media applications.

Previously, yes, it was weekly but now that we have it in the calendar...if there are programmes they will be informed beforehand.Telegram has...communication. He will do what needs to be done through Telegram but with clarity... 
The principal's statement shows his good understanding of the objectives of being a cluster school. With the awareness that becoming a cluster school means becoming a model school in the Penampang district, the principal keeps an open heart to challenges from teachers. Applying wisdom in facing global challenges and myriad human attitudes is no easy feat. From the dialogues above, the researcher finds that the principal is capable in facing risks. It proves the principal is strong dedicated in his duty of providing wholistic education. This speaks of professional practice, whereby the principal prioritises SOP in his duty. Besides managing the school, he is able to guide the teachers under his charge. Among the interview extracts with the informants speaking on the principal are:

Emm..emmm...yes correct emmm. He certainly is...number 1
he is far-sighted...very able in leadership but far-sighted... He
have already done his short-term planning and
what needs to be planned and then he organizes
give ambiguous instructions.

[TB/I6/S5]

The statement above interprets as an attribute of a principal who gives clear instructions that do not confuse the teachers in carrying out their duties in school. This is also one of the principal's strength, whom the informant regards as a leader with foresight and systematic planning.

\section{Discussion}

According to the theoretical framework of The Great Man, the trait approach is a research that focuses on the physical qualities and personality of a leader (Moorhead and Griffin, 1998). The qualities of a great leader are often associated with leaders who possess qualities such as height, character, and intelligence. Leadership success is proven through the theory known as "The Great Man Theory". This theory also summarises those identified as natural leaders as "he is born to be a leader" Great Man (Bass, 1990; Bass dan Bernard, 1989). The Great Man is a theory on attributes regarding the qualities possessed by great humans and focuses on the character of a leader. Spector (2016) explored effective leadership among male leaders with strong physical display. This study found that it is leadership among women principals that explains the domain of positive natural positive attributes by principals. In turn, the professional natural attributes of principal leadership were borne based on the domain of positive natural attributes.

Academicians' findings state leadership as the main factor that brings changes to an organisation (Moo Jun Hau \& Rashad Yazdanifard, 2015). The findings of this study agree that organisational change demands swift action in line with SOP by the principal. This is what defines a principal's professional attributes in leading teachers towards building an excellent school. The impact analysis of the principal's natural attributes from the findings of professional attributes imply that the principal is capable in defining and shaping goals, as well as overcoming conflicts. This strength is reflected the principal's actions in constructing a strategic plan as the direction for the school. The advent of natural attributes of a professional principal needs one who is quick to action besides being a person of reference for teachers in the affairs of education in school. This finding is also in line with that of Norhannan Ramli (2017) who stated that leadership is related to the characteristics, behaviour, and quality of a leader.

The findings of this study help to increase the attributes of principals' professional practice in schools and in turn lead towards organisational excellence. As found through the interviews, a principal who is participative and becomes a person of reference for his teachers is one who joins his teachers in their duties. This element of 'joining in with teachers' means that the principal puts aside his status as a superior and joins in with his teachers in conducting various school programmes. This would finally 
encourage the dignifying of the teaching profession. This study is supported by M. Surji's (2015) study, which identified several factors influencing effective leadership, namely listening, wholehearted, responsible, enthusiastic, assertive, empowerment, supportive, humble, and inspiring in planning. One factor of effective leadership is linked to natural attributes, namely humble and inspiring in planning, as observed from the principal's actions.

This illustrates just how the integration of all the elements of attributes contribute towards the manifestation of a principal's leadership. In carrying out his leadership duties, the principal will be capable of influencing his teachers to collectively achieve the vision and mission of education. The impact felt serves as a ray for the personality and conditioning of students holistically Schools will be viewed as the first institution to gain the trust and confidence of society and the efforts to pool first class human resources. In short, what is expected of the true institution of schools can be instilled by the driving natural attributes of principals apart from efforts to dignify the teaching profession.

\section{Conclusion}

Society accords remarkably high recognition towards educators. Hence, the success of a school is via strategies practised and shaped by its principal and focused driving motivation that forms a united workforce among teachers. Such a phenomenon appropriately fits the needs of the digital era which demands creativity and innovation among educators in mastering the skills of $21^{\text {st }}$ century learning, higher level thinking skills, or school transformation. Various strategy leadership practices such as the highly influential distributed and instructional leadership practices will be able to be practised by principals based on the natural attributes that they possess. As such, principals' attributes remain an interesting and unique area for future studies to improve the orientation of educational leaders, particularly principals. Their willingness to face the risks and ever-growing complex challenges of the digital enables all systems and policies of education to function. Finally, the actions of educational leaders can raise the enthusiasm of teachers in the efforts to restore the high esteem and honour accorded to the teaching profession.

\section{References}

Aydin Balyer, (2017). Trust in School Principals: Teachers' Opinions. Journal of Education and Learning, 6(2).

Ali Moh'd Jubran Saleh, (2014). Principal Leadership and Creativity a Study of Islamic School Principals in Jordan. Fakulty of Education UM. Kl.

Bity Salwana Alias, Ahmad Basri md. Yussuf, Ramlee Mustapha and Muhammad Jani Ibrahim, (2010), Analisis kompetensi Pengetua berdasarkan kualiti peribadi, kemahiran dan amalan dalam bidang pengurusan sekolah menengah Malayisa. Journal Pendidikan Malaysia, 35(2), 31-41.

Bass \& Bernard (1989). Handbook of Leadership : A Survey of Theory and Managerial Application. New York. Free Press.

Hitt \& Turcer. (2016). Systematic Review of Key leader Practices Found to InfluenceStudents Achievement.

DuBrin, A.J (2013). Personality Proactive. Leadership Style. Leadership Research Finding, Practise and Skills.

Desmond M. Tutu. (1984). Attributes of Leadership. Former Archbishop of the Anglican Church \& Nobel Peace Prize winner. ISSN 1609-9982=Verbum Et Ecclesia JR23(3)2002.

Siti Uzairiah (2018). Mudahnya kajian Literatur. Reezqi Publication Selangor.

Ellen, W. E. (2017). Leadership and Policy in School College of Education. Marquette University.

Ellen, W. E. (2017). A Case Study of The implemention of The Co- Principal Leadership model, Leadership and Polocy in School, DOI 10.1080/15700763.2016.12782243.

Ghazali Darusalam \& Sufean Hussin, (2018). Metodologi Penyelidikan Dalam Pendidikan. Amalan dan Analisis Kajian. Edisi kedua. Penerbit UM. Kuala Lumpur. 
Garba Bagobiri, Soaib Asimiran \& Ramli Basri. (2014). Principal's Leadership Attributes : A Predictor for secondary School Effectiveness.

Kelly M. W, (2014). Attributes of Successful Leader in Research. Research Management review, $2(1)$.

Kamaruzaman Moidunny. (2012). Standard Kompetensi Kepengetuaan Sekolah Malaysia(SKKSMK),(atastalian)http://kamaruzamanmoidunny.blogspot.my/2012/09/standardkompetensi-kepengetuaan.html. Dicetak pada 29 April 2017

Kemal M. Surji, (2015). Understanding Leadership and Factors that Influence Leaders' Effectiveness January 2015. DOI: 10.7176/EJBM/7-33-2015-03

Jensen B Hunter A, Lambert T and Clark A (2015). Aspiring principal Preparation, prepared for the austrlian institute for teaching and school leadership. Melbourne Australia: AITSL

Jemaah Nazir (2001) Pernyataan Dasar Standard Tinggi Kualiti Pendidikan (SKTP) Kuala Lumpur.

James Ang Jit Eng. (2018). Kepimpinan Instruksional. Satu panduan Praktikal. PTS Professional. Kuala Lumpur.

Liamputtong, P.(2014). Kaedah Penyelidikan Kualitatif. Penterjemah

Haliza Mohd. Riji, Shamsuddin Ahmad. Edisi Ketiga. UPM. Serdang, Selangor.

Moorhead G \& Griffin R . (1998). Organizational Behavior: managing People and Organizational. Ed ke-5. Boston Houghton Miffin.Co.

Mustamin, \& Yasin, M. A. (2012). The Competence of School Principals : What Kind of Need Competence for School Success? Journal of Education and Learning, 6(1), 33-42

Mitgang, Lee (Ed). (2012). The Making of PrinciPal : Five Lessons in Leadership Traning.

Manoj Kumar Sharma and Shilpa Jain, (2013).Manoj Kumar Sharma and Miss. Shilpa Jain, Leadership Management: Principles, Models and Theories. Global Journal of Management and Business Studies, 3(3), 309-318.

Moo Jun Hao \& Rashad Yazdanifard, (2015). How Effective Leadership can Facilitate Change in Organizations through Improvement and Innovation. Global Journal of Mgt and Business Research administration and Mgt, 15(9).

Norlia Goolamalty \& Jamil Ahmad, (2014). Attributes of School Leaders Towards Achieving Sustainable Leadership : A Factor Analysis. Journal of Educational and Learning, 3(1).

Norhannan binti Ramli et.(2017).Fungsi Komitmen sebagai Medator bagi Hubungan Biah sekolah terhadap Prestasi Guru pendidikan Islam. O-Jie Online journal of Islamic Edu.

Pelan Pembangunan Pendidikan Malaysia (PPPM ), (2013-2025). KPM.

Phillip Hallinger, Shengnen Liau and Parnaree (2017). Http://dol.org/101080/0305

Patton.M. (1990). Qualitative Evalution and Research Methods. Beverly Hill.CA.Sage. Designing Qualitative Studies.

Patton.M. (2002) Qualitative Research and Evaluation Methods. 3 Edition.

Spector, B.A.(2016). Carlyle, Freud and The Great Man Theory More fully Considered. Leadership, $12(20,250-260$.

Stogdill, R (1974). Handbook of Leadership A Survey of Theory and Research. New York The Free Press.

Sharifah Madinah bt. Syed Abdul Rahman, (2007). The Principal Factor. Sasbadi Selangor Malaysia.

Sohiron, Ahmad Syukri \& Kasful Anwar US, (2019). Kajian Teori dan Hasil Penelitian Pendidikan. Indonesian Journal of Islamic Management, 2(1), 43-52.

Seale, Gobo, Gubrium, \& Silverman, (2005). Qualitative Research Practice. SAGE Publications Ltd. London.

Stake, R.E. (2010). Qualitative Research Studying How Things Work. Guilford Publications.

Robert K. Yin, (2003). Case Study Researh Design and Methods. Third Edition. Sage Publications.

Roselena Mansor, (2015). Kepimpinan Berkualiti: Perspektif mengenai Kompetensi yang Diperlukan untuk Memimpin dengan Berkesan. Jurnal Pengurusan, 45, 143-154.

Tschannen-moran, M \& Gareis, C.R. (2015). Principals, Trust and Cultivating Vibrant Schools. Societies 5. 256-276.http://doi.org/10.3390/soc5020256.

Tun M, (2016). Inilah Perjuangan. Publising House. Selangor.

Wan Noor Adzmin binti Mohd Sabri and Suria Baba. (2017) Julai. Jurnal Kepimpinan Pendidikan IPG kampus Pendidikan Teknik KPM

Yin, R.K (2003). Case Study Research, Design and Method. Sage. Thousand Oaks. California. 